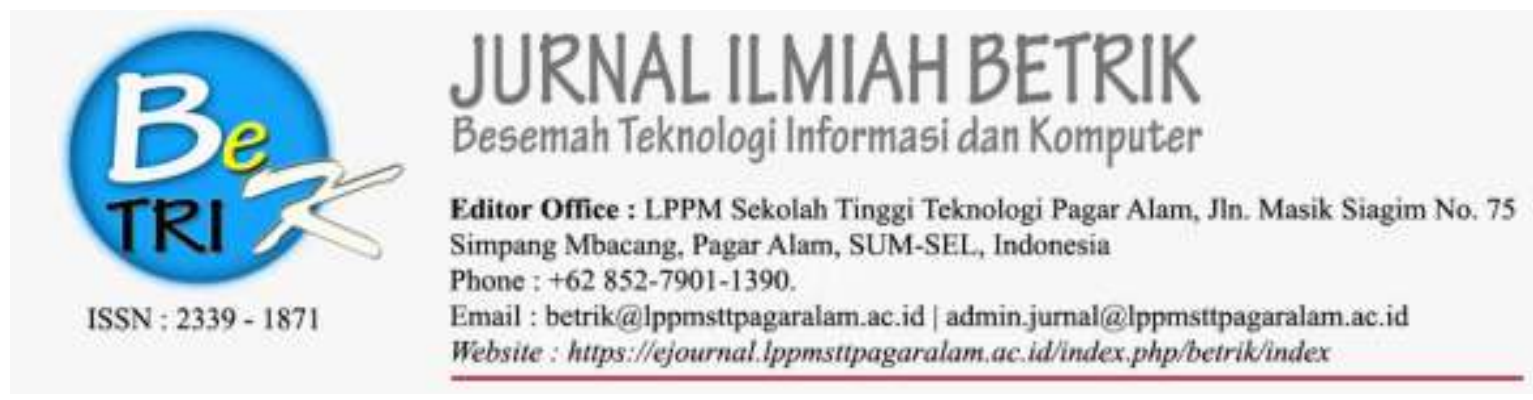

\title{
Rancang Bangun Website TK-SD Pada Fluency Kids Di Kota Pagar Alam
}

\author{
Evi Septriani ${ }^{1}$, Yeni $^{2}$ \\ Dosen Sekolah Tinggi Teknologi Pagar Alam ${ }^{1}$, Mahasiswa Sekolah Tinggi Teknologi Pagar Alam ${ }^{2}$ \\ Jalan Masik Siagim No.75 Simpang Mbacang Kec.Dempo Tengah Kota Pagar Alam \\ Sur-el:
}

\begin{abstract}
The purpose of this study is the Build website at SMP Negeri 3 Kota Pagar Alam in order to help users get information about the activities of student learning, teaching, school achievement, teachers and students. With her website at SMP Negeri 3 Kota Pagar Alam is expected to provide fast, precise and accurate for those in need. Currently in SMP Negeri 3 Kota Pagar Alam despite the availability of the Internet however, the unavailability of a website to facilitate the search of information about SMP Negeri 3 Kota Pagar Alam. Systems Development Method used method of Web Engineering with stage-phases: Custumer Communication, Planning, Modeling, Contruction and Deployment. Design using UML and Programming using PHP. The results of the research available Fluency Kids Website Pagar Alam Alam can be accessed by the user wanted to know information Kids Fluency Pagar Alam.
\end{abstract}

Keywords: Website, Design, Web Engineering, UML and PHP

\begin{abstract}
Abstrak: Tujuan dari penelitian ini adalah Membangun website pada SMP Negeri 3 Kota Pagar Alam guna membantu user mendapatkan informasi tentang kegiatan siswa belajar, mengajar, prestasi sekolah, guru dan siswa. Dengan di buatnya website SMP Negeri 3 Kota Pagar Alam di harapkan dapat memberikan informasi yang cepat, tepat dan akurat bagi pihak yang membutuhkan. Saat ini di SMP Negeri 3 Kota Pagar Alam walaupun sudah tersedianya jaringan internetakan tetapi, belum tersedianya website yang dapat mempermudah pencarian informasi tentang SMP Negeri 3 Kota Pagar Alam. Metode Pengembangan Sistem yang digunakan adalah metode Web Engineering dengan tahap-tahapan : Custumer Communication, Planning, Modeling, Contruction dan Deployment. Perancangan menggunakan UML dan Pemrograman menggunakan PHP. Hasil dari penelitian tersedianyaWebsiteFluency Kids Kota Pagar Alam Alam ini dapat di akses oleh user yang ingin mengetahui informasiFluency Kids Kota Pagar Alam.
\end{abstract}

Kata Kunci: Website, Rancang Bangun, Web Engineering, $U M L$ dan $P H P$

\section{PENDAHULUAN}

Pesatnya perkembangan teknologi informasi dan komunikasi telah mempengaruhi paradigma berpikir sebagian besar masyarakat dunia, termasuk di Indonesia. Kini teknologi tidak hanya bisa dinikmati oleh para teknokrat melainkan sudah menjadi konsumsi publik. Banyak sarana yang telah terambah oleh teknologi, bahkan dapat dikatakan akan sulit 
untuk menemukan satu bidang yang belum tersentuh teknologi. Ini berarti teknologi telah menjadi bagian penting dalam kehidupan umat manusia..Perkembangan teknologi yang pesat harus diimbangi dengan perkembangan kemampuan manusia sebagai subyek pengguna yang berperan sebagai pihak yang memanfaatkan teknologi untuk berbagai kepentingannya. Kini popularitas internet sudah memasuki dunia pendidikan dengan peranan dan fungsi yang relatif belum tergantikan oleh media lain. Internet digunakan dengan berbagai kepentingan institusi pendidikan baik untuk kepentingan administratif maupun edukatif, mulai dari lembaga TK, SD, SMP, SMA, hingga perguruan tinggi. Berkembangnya kemajuan teknologi saat ini, Sekolah perlu mempromosikan dirinya melalui website Sekolah sehingga masyarakat dengan mudah mengakses dan mengetahui segala sesuatu mengenai Sekolah tersebut dengan cepat. Sehingga penulis bermaksud merancang dan membangun website Sekolah sebagai solusi atas masalah tersebut.

Pada sekolah TK-SD Fluency Kids Kota Pagar Alam belum tedapat website yang bergunan untuk memperkenalkan sekolah ke masyarkat luas, yang mencangkup segala sesuatu yang bersangkutan dengan dunia pendidikan. Tentu saja pembuatan website ini sangat berguna bagi siswa/siswi, staf, guru dan masyarakat. Dan juga dapat digunakan sebagai media promosi, apalagi sekolah TK-SD Fluency Kids Kota Pagar Alam terbilang masih sangat baru. Sekolah ini berdiri di tahun 2009. Dalam pembuatan website ini kompunen-kompunen yang ada dalam suatu wadah pendidikan TK-SD tersaji seperti guru, siswa, karyawan bahkan calon siswa/siswi yang yang mendaftar saling berinteraksi.

Rumusan masalah yang akan dibahas dalam penelitian ini adalah Bagaimana membangun website TK-SD Fluency Kids Kota Pagar Alam Menggunakan MySQL dan PHP ?

Tujuan dari penelitian dan pengembangan di TK-SD Fluency Kids adalah memperkenalkan profil sekolah ini dengan kalayak umum guna menarik minat masyarakat untuk menimbah lmu di TK-SD Fluency Kids Pagar Alam.

\section{METODOLOGI PENELITIAN}

\subsection{Metode Pengembangan Sistem}

Dalam pengembangan sistem ini metode pengembangan mneggunakan Metode Web engineering( rekayasa web). Karena metode ini memberikan ide bagi pengembang maupun user tentang cara sistem akan berfungsi dan akan dikembangkan. Roger S. Pressman (2010:17).

\section{a) Perencanaan}

Alur yang rumit dapat di sederhanakan jika terdapat suatu peta. Suatu proyekperangkat lunak pada dasarnya merupakan suatu alur yang rumit dan kegiatan perencannaan perangkat lunak tersebut menciptakan suatu "peta" yang membantu membimbing tim perangkat lunak ketika mereka malakukan perjalanan. Peta perangkat luank tersebut yang disebut sebagai rencana proyek perangkat lunak. Mengartikan kerja rekayasa perangkat lunak dengan menggambarkan tugas-tugas teknis yang harus dilakukan, resiko-resiko yang mungkin muncul, sumber daya yang akan dibutuhkan, produk- 
produk kerja yang harus di hasilkan, dan jadwaljadwal kerja.

b) Komunikasi

Sebelum pekerjaan teknis apapun di mulai, sangatlah penting untuk berkomunikasi dan berkolaborasi dengan pelanggan (dan para pemangku kepentingan lainya). Maksudnya adalah untuk memahami tujuan-tujuan atas proyek perangkat lunak yang sedang dikembangkan da mengumpulkan kebutuhankebutuhan yang akan membantu mengartikan fitur-fitur perangkat lunak beserta fungsifungsinya.

\section{c) Pemodelan}

Tujuan dari aktifitas ini adalah menjelaskan hal apa saja yang memang diperlukan/di butuhkan pada aplikasi yang akan di bangun dan solusi yang ditawarkan yang dapat di harapkan dapat menjawab apa yang bersirat dari hasil-hasil analisa dan pengumpulan data.

d) Kontruksi

Kegiatan ini menggabungkan pembentukan kode-kode (kode generation) bisa secara manual maupun otomatis dan pengujian yang sangat di butuhkan untuk menemukan kekeliruan-kekeliruan/ kesalahan-kesalahan dalam kode program komputer yang dihasilkan sebelumnya.

e) Deployment

Perangkat lunak disajikan kepada pelanggan yang kemudian mengevaluasi produk yang disajikan dan akan memberikan umpan balik berdasarkan eveluasi tersebut.

\subsection{Rancang Bangun}

Rancang bangun merupakan serangkaian prosedur untuk menterjemahkan hasil analisa dari sebuah sistem kedalam suatu bahasa pemograman untuk mendeskripsikan dengan detail bagaimana kompunen-kompunen sistem di implementasikan (Pressman, 2002:19 ). Sedangkan pengertian bangun atau pembangunan sistem adalah kegiatan menciptakan sistem baru maupun mengganti atau memperbaiki sistem yang telah ada baik secara keseluruhan maupun sebagian (Pressman,2002:23).

\subsubsection{Pengertian Website}

Website adalah keslirihan halamanhalaman web yang terdapat dari sebuah domain yang mengandung informasi. Sebuah website biasanya dibangun atas banyak halaman web yang saling berhubungan. Hubungan antara banyak halaman web dengan banyak halaman web yang lainya, antara bagaian dalam halaman web yang sama disebut Hyperlink sedangkan teks yang dijadikan media penghubung disebut Hyperteks. Sebuah website dapat di akses dalam browser, yaitu perangkat lunak untuk mengakses halaman-halaman web, seperti internet explorer, Mozilla Firefox, Opera, Safari, Chrome dan lainya.

\subsubsection{Pengertian Internet}

Internet merupakan kepanjangan dari interconnection Networking. Internet adalah jaringan komputer yang saling terhubung di seluruh dunia tanpa mengenal batas teritorial hukum dan budaya (Muhammad Rafi'i 2010 :1 ).

\subsubsection{Unified Modelling Language (UML)}




\section{UML (Unified Modeling Language)}

adalah sebuah bahasa yang telah menjadi standar dalam industri untuk visualisasi, merancang dan mendokumentasikan sistem piranti lunak. (Yuni Sugiarti: 2013:34).

\section{Use Case Diagram}

Use case diagram menggambarkan fungsionalitas yang diharapkan dari sebuah sistem. Yang ditekankan adalah "apa" yang diperbuat sistem, dan bukan "bagaimana". Sebuah Use Casemerepresentasikan sebuah interaksi antara aktor dengan sistem. Use case merupakan sebuah pekerjaan tertentu, misalnya login ke sistem, meng-create sebuah daftar pegawai, dan sebagainya. Seorang/sebuah aktor adalah sebuah entitas manusia atau mesin yang berinteraksi dengan sistem untuk melakukan pekerjaan-pekerjaan tertentu.

\section{Class Diagram}

Class Diagram adalah sebuah spesifikasi yang jika diinstansiasi akan menghasilkan sebuah objek dan merupakan inti dari pengembangan dan desain berorientasi objek. Class menggambarkan keadaan (atribut/properti) suatu sistem, sekaligus menawarkan layanan untuk memanipulasi keadaan tersebut (metoda/fungsi).

\section{Statechart Diagram}

Statechart diagram menggambarkan transisi dan perubahan keadaan (dari satu state ke state lainnya) suatu objek pada sistem sebagai akibat dari stimuli yang diterima. Pada umumnya statechart diagram menggambarkan class tertentu (satu class dapat memiliki lebih dari satu statechart diagram).

\section{Actifity Diagram}

Activity diagrams menggambarkan berbagai alir aktivitas dalam sistem yang sedang dirancang, bagaimana masing-masing alir berawal, decision yang mungkin terjadi, dan bagaimana mereka berakhir. Activity diagram juga dapat menggambarkan proses paralel yang mungkin terjadi pada beberapa eksekusi.

\section{Sequence Diagram}

Sequence diagram menggambarkan interaksi antar objek di dalam dan di sekitar sistem (termasuk pengguna, display, dan sebagainya) berupa message yang digambarkan terhadap waktu. Sequence diagram terdiri atar dimensi vertikal (waktu) dan dimensi horizontal (objek-objek yang terkait).

\section{Collaboration Diagram}

Collaboration diagram juga menggambarkan interaksi antar objek seperti sequence diagram, tetapi lebih menekankan pada peran masing-masing objek dan bukan pada waktu penyampaian message.

\section{Component Diagram}

Componentdiagram menggambarkan struktur dan hubungan antar komponen piranti lunak, termasuk ketergantungan (dependency) di antaranya.

\section{Deployment Diagram}

\section{Deployment/physical}

diagram menggambarkan detail bagaimana komponen di-deploy dalam infrastruktur sistem, di mana komponen akan terletak (pada mesin, server atau piranti keras apa), bagaimana kemampuan 
jaringan pada lokasi tersebut, spesifikasi server, dan hal-hal lain yang bersifat fisikal.

\subsection{Perancangan}

\subsubsection{Use Case Diagram}

Dengan menggambarkan funsionalitas yang di harapkan dari sebuah sistem. Yang ditekankan adalah " apa "yang diperbuat sistem dan bukan " bagaimana " sebuah use case mempresentasikan sebuah interaksi antara actor dengan sistem. Use Case diagram Admin diharuskan melakukan login dan dihadapkan pada beberapa menu pilihan seperti input data berita, input info sekolah, input data guru, input data pelajaran, input data album galeri, atur buku tamu, manajemen admin, dan atur tampilan web.

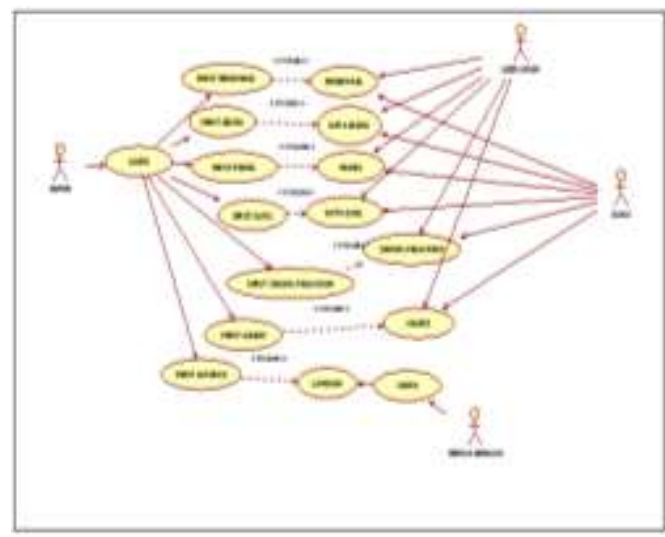

Gambar 1. Use Case Diagram

\subsubsection{Activity Diagram Admin}

Pada bagain ini penulis merinci kembali kegiatan aktor dengan menggambarkan kegiatan admin interaksinya dengan sistem, admin harus melakukan login untuk dapat masuk ke backend, jika username dan password-nya benar, maka tampil menu untuk input berita, verfikasi data dan update data.

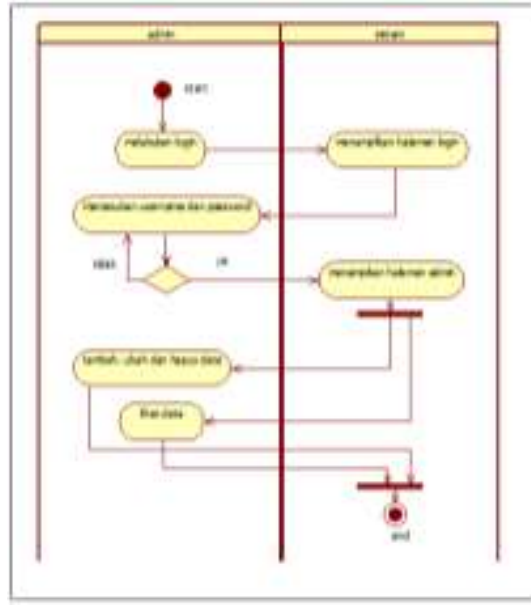

Gambar 2. Activity Diagram

\subsubsection{Desain Form}

\subsubsection{Desain Home}

Desain halaman utama merupakan tampilan pertama saat kita membuka website TK-SD Flency Kids Kota Pagaralam.

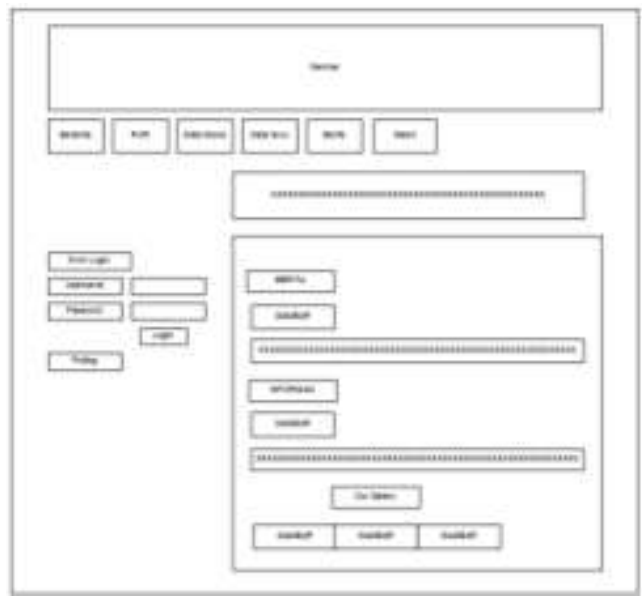

Gambar 3. Halaman Home

\section{HASIL DAN PEMBAHASAN}

\subsection{Hasil}

Implementasi sistem adalah langkahlangkah atau prosedur-prosedur yang dilakukan 
dalam menyelesaikan desain sistem yang telah disetujui, untuk menguji, menginstal dan memulai sistem baru atau sistem yang diperbaiki untuk menggantikan sistem yang lama.

Implementasi yang telah sesuai harus diuji coba sehingga dapat diketahui kehandalan dan sistem yang ada telah sesuai dengan apa yang diinginkan. Tujuan implementasi sistem ini adalah

1. Menyelesaikan desain sistem yang ada dalam dokumen desain sistem yang disetujui, menyusun dokumen baru atau dokumen-dokumen yang diperbaiki.

2. Menulis, menguji dan mendokumentasikan program-program dan prosedur-prosedur yang diperbaiki oleh desain sistem yang disetujui.

3. Memastikan bahwa user dapat mengoperasikan sistem yang baru

4. Memperhitungkan bahwa sistem memenuhi permintaan user yaitu dengan menguji sistem secara menyeluruh dan Memastikan bahwa konversi sistem yang baru berjalan secara benar yaitu dengan merencanakan, mengontrol dan melakukan instalasi sistem baru secara benar.

Langkah - langkah mengoperasikan Website :

1. Terlebih dahulu aktifkan > Xampp > Lalu pilih dan klik Xampp Control Panel.

2. Maka akan tampil window "Xampp Control Panel Application

3. Pada pilihan "Modules", klik button start untuk Apache dan MySQL.

4. Web server dan database server telah aktif
5. Setelah Web server dan database server telah aktif, aktifkan Mozilla firefox lalu panggil localhost/data_fc lalu klik OK

6. Maka akan tampil website Fluency Kids.

\subsection{Pembahasan Tampilan Halaman Website}

\subsubsection{Pembahasan Tampilan Home}

Halaman ini akan muncul saat kita membuka TK-SD Fluency Kids Kota Pagar Alam dari halaman ini kita dapat memasuki halaman home dengan memasukan username dan password sesuai dengan data yang kita masukan.

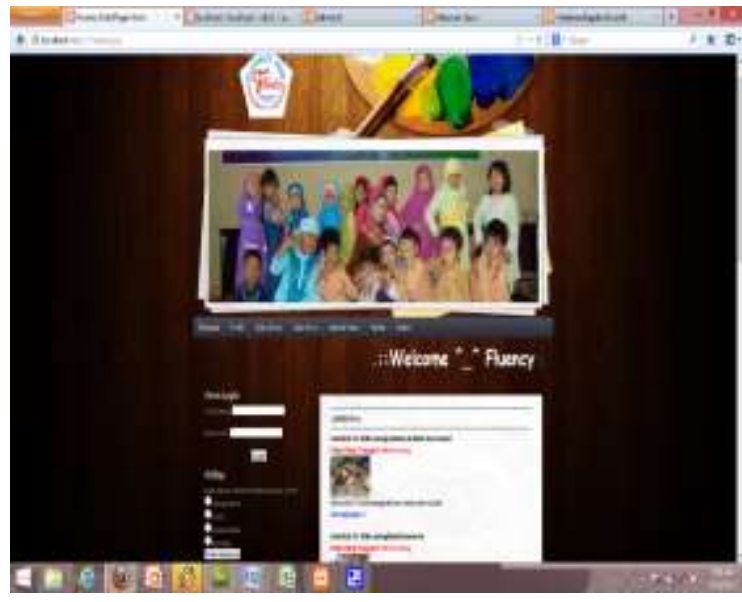

Gambar 4. Halaman Home

\subsubsection{Halaman Home Admin}

Sebelum kita membuat, mengolah website menggunakan PHP MyAdmin terlebih dahulu untuk login ke halaman administrator website. 


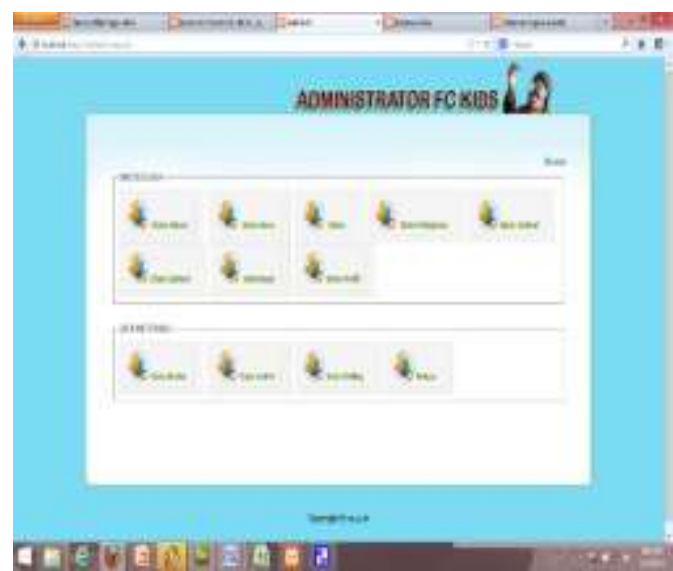

Gambar 5. Home Admin

\subsubsection{Halaman Input Data Guru}

Halaman ini digunakan untuk penginputan data guru yang telah terdaftar di sistem TK-SD Fluency Kids Kota Pagar Alam, penginputan data guru ini dilakukan oleh admin sistem. Halaman nantinya dapat di gunakan oleh guru untuk mengakses fasilitas yang di sediakan oleh website TK-SD Fluency Kids Kota Pagar Alam.

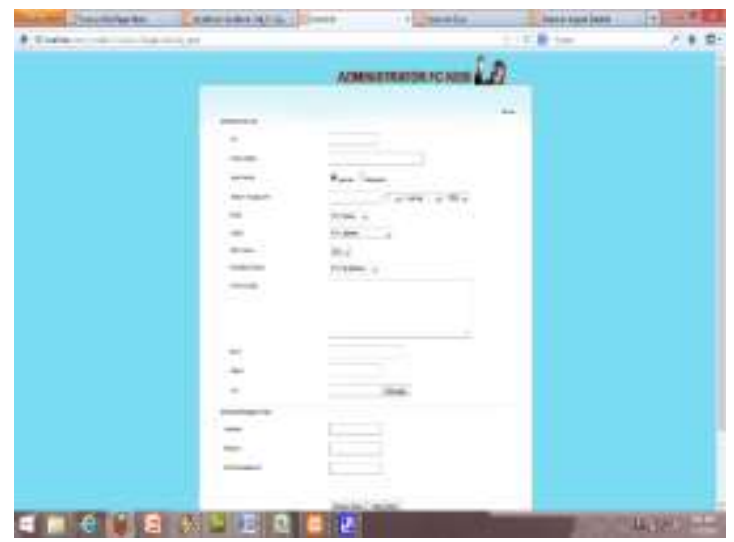

Gambar 6. Input Data Guru

\subsubsection{Halaman Input Data Siswa}

Halaman ini digunakan untuk penginputan data siswa yang telah terdaftar di sistem TK-SD Fluency Kids Kota Pagar Alam, penginputan data siswa ini dilakukan oleh admin sistem.

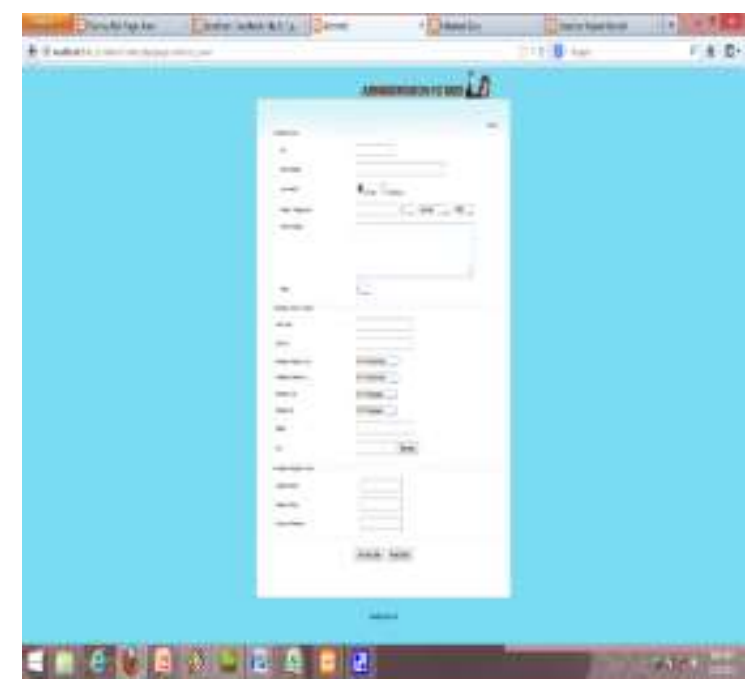

Gambar 7. Input Data Siswa

\subsubsection{Halaman Input Mata Pelajaran}

Admin melakukan akses kedalam sistem TK-SD Fluency Kids Kota Pagar Alam dan melakukan iput mata pelajaran pada halaman yang disediakan untuk iput mata pelajaran.

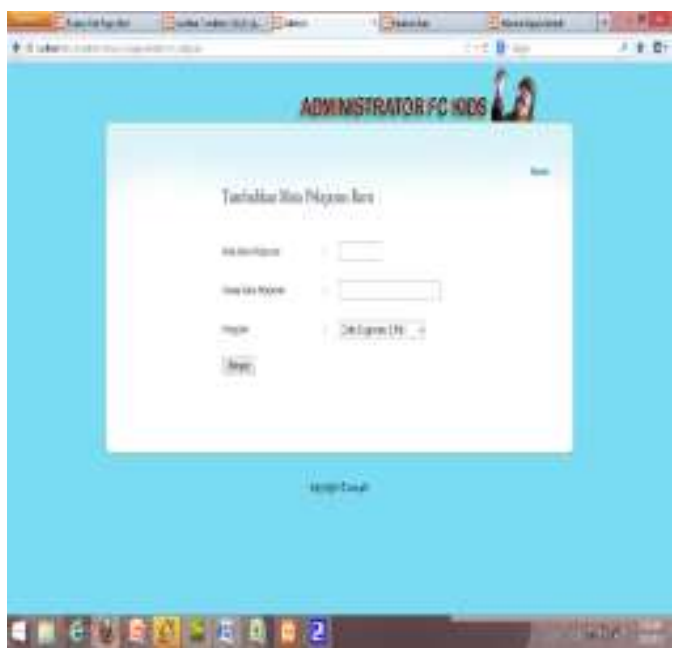

Gambar 8. Input Mata Pelajaran

\subsubsection{Data Mata Pelajaran}

Pada halaman ini kepala sekolah dan guru terlebih dahulu harus melakukan pencarian mata pelajaran terlebih dahulu untuk dapat melihat mata pelajaran yang diinginkan. 


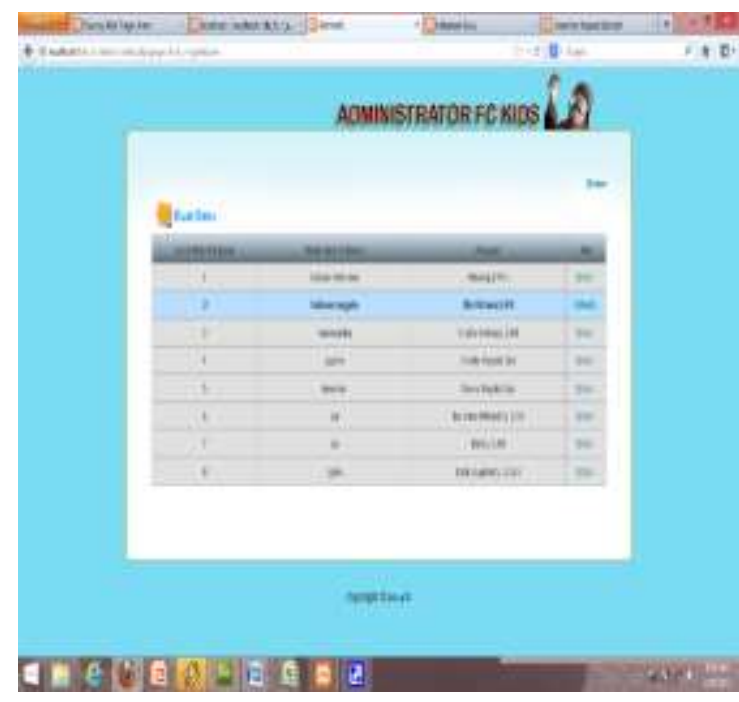

Gambar 9. Data Mata Pelajaran

\subsubsection{Input Jadwal Pelajaran}

Admin melakukan akses kedalam sistem TK-SD Fluency Kids Kota Pagar Alam dan melakukan iput jadwal pelajaran pada halaman yang disediakan untuk iput jadwal pelajaran.

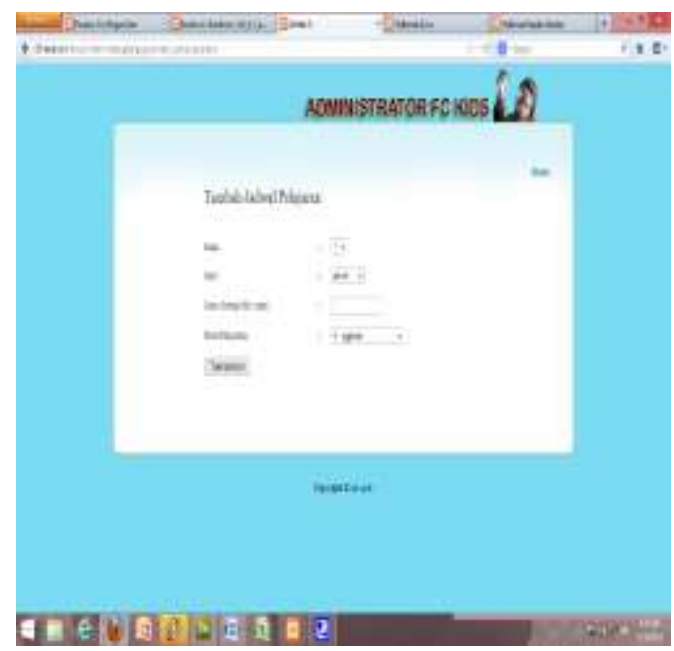

Gambar 10. Input Jadwal Pelajaran

\subsubsection{Data Jadwal Pelajaran}

Pada halaman ini admin terlebih dahulu harus melakukan login untuk melakukan pencarian jadwal pelajaran.

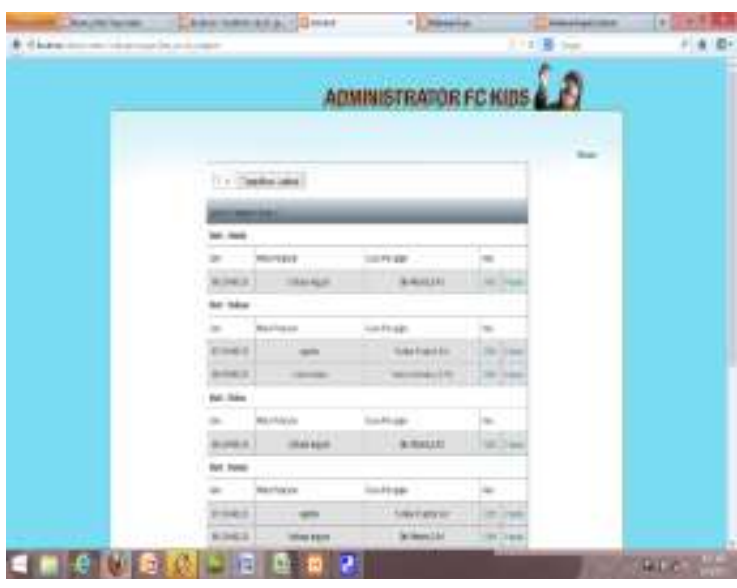

Gambar 11. Data Jadwal Pelajaran

\subsubsection{Halaman Kelola Berita}

Halaman ini menampilkan pengolahan data berita oleh admin, baik itu penambahan atau pengurangan data baru.

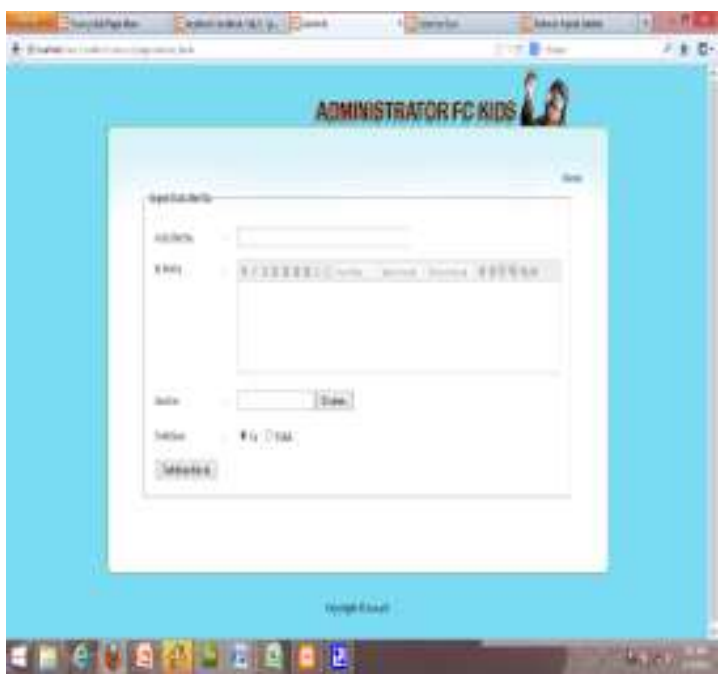

Gambar 12. Kelola Berita

\subsubsection{Halaman Input Profil}

Halaman ini menampilkan pengolahan data profil oleh admin, baik itu penambahan atau pengurangan data baru. 


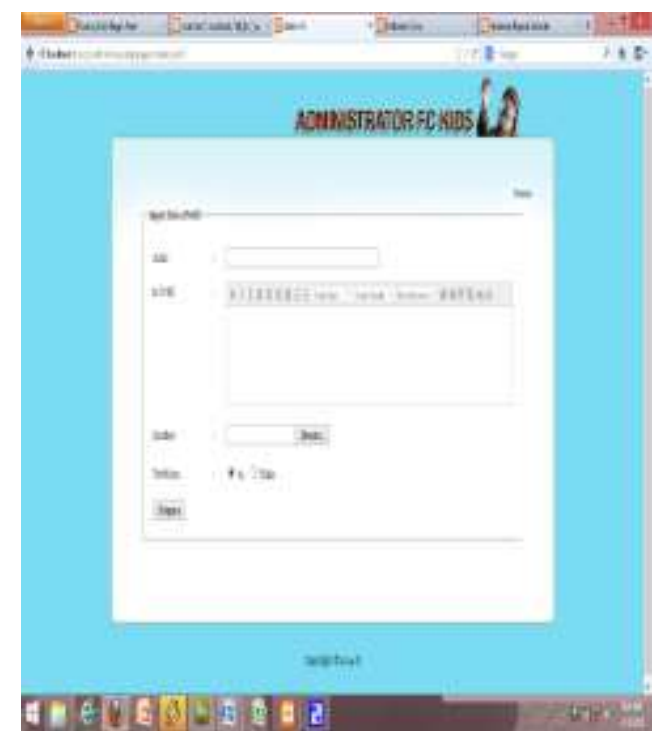

Gambar 13. Input Profil

\subsubsection{Halaman Input Galeri}

Halaman ini menampilkan pengolahan data galeri oleh admin, baik itu penambahan atau pengurangan data baru.

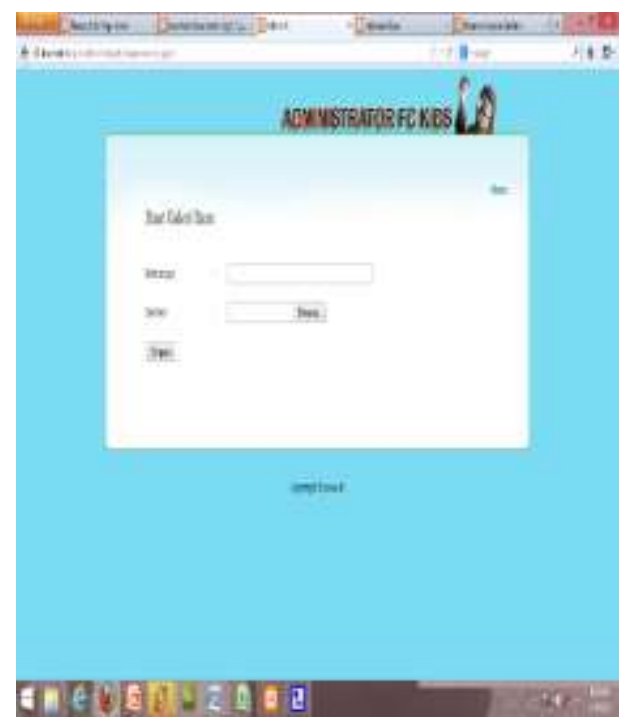

Gambar 14. Input Galeri

\section{SIMPULAN}

Dalam penelitian ini telah diuraikan bagaimana perancangan sistem dalam membangun website TK-SD Fluency Kids Kota Pagar Alam. Maka peneliti dapat menyimpulkan:
1. Telah diselesaikan WebsiteFluency Kids Kota Pagar Alam ini dapat di akses oleh user yang ingin melihat data pada Fluency Kids Kota Pagar Alam.

2. Pengembangan aplikasi ini mencangkup beberapa fungsi ke Sekolah Fluency Kids. Seperti Pengelolaan Data Siswa, Pengelolaan Data Guru dan Pengelolan Laporan.

3. Desain interface yang menarik sangat diperlukan dalam merancang sebuah sistem informasi agar para user nyaman menelusuri website ini.

4. Sasaran dari website ini adalah guru, kepala sekolah dan user yang dapat setiap saat memanfaatkan fasilitas TKSD Fluency Kids Kota Pagar Alam. 


\section{RUJUKAN}

Arief, Rudyanto, M. 2011. Pemrograman Web

Dinamis Menggunakan PHP \& MySQL.

Penertbit Andi. Yogyakarta.

Jugiyanto H.M, 2000. Pengenalan Komputer.

Penerbit Andi. Yogyakarta.

Pressman,Roger S. 2002. Rekayasa Perankat

Lunak. Penerbit Andi. Yogyakarta.

Sulaini, Iskandar. 2008. Pengenalan Internet.

Universitas Bina Darma Palembang.

Palembang.

Widodo Pudjo Prabowo. 2011. Menggunakan

UML. Penerbit Informatika. Bandung 